Nadestano 15.11.2018 r.; zaakceptowano 18.12.2018 r.

\title{
ZARYS DAWNEGO GÓRNICTWA I PRZEROBU SUROWCÓW ILASTYCH LUBSKA, JASIENIA I ICH OKOLIC (POWIAT ŻARSKI)
}

\author{
Wojciech KACZAN \\ Doktorant Wydziału Geoinżynierii, Górnictwa i Geologii Politechniki Wrocławskiej \\ Lubsko, Jasień, Sommerfeld, Gassen, \\ surowce ilaste, ceramika budowlana, cegielnie
}

\begin{abstract}
Lubsko (dawniej Sommerfeld) to miasto położone w południowo-zachodniej części województwa lubuskiego. Jego morfologia została istotnie zmieniona w wyniku odkrywkowej eksploatacji surowców ilastych prowadzonej na przemysłową skalę w XIX i XX w. Celem tej publikacji jest uporządkowanie obecnej wiedzy na temat geologii i historii górniczej Lubska, Jasienia oraz ich okolic. Dodatkowo, wynikiem przeprowadzonego zwiadu terenowego jest dokumentacja fotograficzna reliktów górniczych. Studium literaturowe zostało przeprowadzane na bazie dokumentów, tekstów i map pochodzących z Biblioteki Publicznej Miasta i Gminy Lubsko, Archiwum Państwowego w Zielonej Górze, prywatnych zbiorów geologa - pana A. Kuźniara, a także baz danych i źródeł internetowych. Przeprowadzono również rozmowy z byłymi pracownikami zakładów - mechanikiem, panem Piotrem Kaczanem, głównym geologiem, panem Alfredem Kuźniarem i kierownikiem produkcji, panią Eugenią Kuźniar.
\end{abstract}

\section{Geologia obszaru badań}

Lubsko to miasto o populacji około 15 tysięcy mieszkańców. Położone jest w powiecie żarskim, w południowo-zachodniej części województwa lubuskiego (ryc. 1). Najstarsze utwory były rozpoznane w latach 1962-1966 poprzez wiercenia poszukiwawcze ropy naftowej. Do utworów tych należą paleozoiczne zlepieńce, wapienie, granity, anhydryty oraz piaskowce o różnym zabarwieniu (Myk, 1977). W następnym dziesięcioleciu w okolicach Lubska i Jasienia rów- 
nież były wykonywane głębokie otwory badawcze. Najgłębszy wykonany w tej okolicy to Nowa Rola P-9 o głębokości 1466 m, nawiercony w roku 1977 (www.otworywiertnicze..., 2019). Do najstarszych rozpoznanych w nim skał należą spękane porfiry i melafiry oraz leżące nad nimi karbońskie piaskowce przewarstwione zlepieńcami i iłowcami (Bartczak, 2001). Kolejny otwór - Górzyn P-3, był nawiercony w roku 1975 na głębokość $1218 \mathrm{~m}$. Jest on zlokalizowany kilka kilometrów od Lubska. Najstarsze rozpoznane w nim utwory to permskie zlepieńce, piaskowce, wapienie, anhydryty oraz sól kamienna, dolomity i iłowce. W mieście Jasień dokonano w roku 1989 wiercenia otworu Jasień P-4, o głębokości 1054 m (www.otworywiertnicze..., 2019).

Utwory mezozoiczne to głównie triasowe piaskowce, iłowce lub mułowce, wapienie i margle pstrego piaskowca oraz margle, wapienie i dolomity wapienia muszlowego (Maćków i in., 2006).
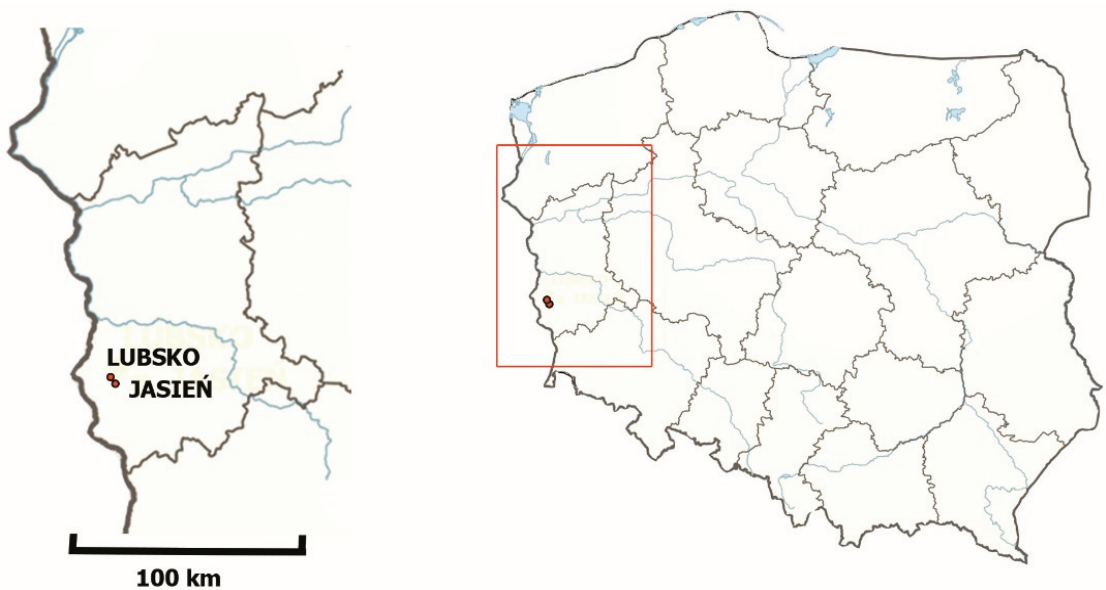

Ryc. 1. Położenie Lubska i Jasienia na mapie Polski i województwa lubuskiego (na podst. wikipedia.com NordNordWest)

Fig. 1. The location of Lubsko and Jasien on the map of Poland and the Lubuskie province (adopted from wikipedia.com NordNordWest)

Neogen jest reprezentowany przez osady mioceńskie i plioceńskie. W zachodniej części regionu utwory miocenu wykształciły się w postaci formacji węgla brunatnego, a w zachodniej części Równiny Lubszy oraz Doliny Nysy mają postać mułków, iłów, węgla brunatnego oraz drobnych piasków. W części wschodniej opisywanego obszaru występują nieliczne wychodnie utworów tego okresu. Pozostałe tereny przykryte są osadami plejstoceńskimi oraz holoceńskimi. Plejstocen reprezentowany jest przez utwory piaszczyste, piaszczystożwirowe oraz gliniaste. Ich miąższość wynosi od kilku do kilkunastu, a miejscami nawet do kilkudziesięciu metrów (Myk, 1977). Holocen reprezentują 
głównie utwory wypełniające doliny rzeczne oraz różne pod względem genetycznym zagłębienia podłoża. Są to głównie piaski, żwiry, namuły piaszczyste, ale także gytia, torfy i namuly torfiaste (Bartczak, 2001).

Na obszarze gminy Lubsko oraz Jasień występują udokumentowane złoża węgla brunatnego oraz surowców ilastych. Stwierdzono także występowanie torfów dla celów rolniczych, jednak występują one na terenach obszarów chronionych lub nie spełniają wymaganych kryteriów złożowych, wobec tego są to tylko obszary perspektywiczne (geolog..., 2018). Podstawową bazę surowcową dla przemysłu ceramicznego $\mathrm{w}$ tym rejonie stanowiła najwyższa część górnomioceńskiej serii poznańskiej (Bartczak, 2001).

Obecnie w Bilansie Zasobów Złóż Kopalin w Polsce (Szuflicki i in., 2018) widnieje 7 złóż surowców ilastych na terenie gmin Lubsko i Jasień. Są to: Glinka Górna, Lubsko - Dachówczarnia I, Lubsko - Dachówczarnia II, Lubsko - Kaflarnia, Lubsko - Szamotownia oraz Jasień II (zagospodarowane). W roku 2000 z bilansu wykreślono złoże Jasień I, a w roku 2017 złoże Budych I (Szuflicki i in., 2018). Do przedsiębiorstwa zarządzającego zakładami ceramiki budowlanej na tym terenie przez pewien okres należało także złoże Drzeniów, leżące na granicy gminy Jasień i Tuplice oraz złoże Tuplice leżące w gminie Tuplice, dlatego również one zostały uwzględnione w tabeli 1.

Złoże Glinka Górna o powierzchni 3,25 ha budują głównie pstre i szarozielonawe iły serii poznańskiej, wykazujące przejścia do mułków i piasków ilastych, zwykle drobnoziarnistych. Iły poznańskie zawierają 50-70\% minerałów ilastych. Głównym minerałem jest beidellit, a towarzyszą mu kaolinit oraz podrzędnie illit. Dodatkowo, licznie występuje kwarc, muskowit oraz getyt (Maćków i in., 2006; Kozydra \& Wyrwicki, 1978).

Złoże Lubsko-Dachówczarnia I składa się z iłów pstrych w górnej części złoża, oraz iłów zielonawoszarych w niższych partiach. Zawartość minerałów ilastych wynosi $65-70 \%$ z przewagą beidellitu nad kaolinitem i illitem. Występują także kwarc, muskowit, getyt, hematyt oraz śladowo jarosyt i gips (Kozydra \& Wyrwicki, 1978). Złoże udokumentowano na 9,0 ha (Maćków i in., 2006).

Złoże Lubsko-Dachówczarnia II zajmuje powierzchnię 8,59 ha (Maćków $i$ in., 2016). Zbudowane jest z pstrych oraz szarozielonawych iłów, wykazujących przejścia do mułków. W składzie ziarnowym występuje 45-65\% minerałów ilastych oraz $10 \%$ frakcji piaskowej. Główny składnik to ponownie beidellit, współwystępuje z nim kaolinit przeważający ilościowo nad illitem. Wyróżnić można także występowanie kwarcu, muskowitu, getytu, hematytu, pirytu i skaleni (Kozydra \& Wyrwicki, 1978).

Złoże Lubsko-Szamotownia udokumentowano na powierzchni 20,5 ha. Nakład składa się z warstwy gleby, glin i piasków piaszczysto-żwirowych. Górnomioceńskim iłom towarzyszą piaski, występujące w formie soczewkowatych wkładek (Maćków i in., 2006). 
Tabela 1. Wykaz złóż surowców ilastych gmin Lubsko, Jasień oraz Tuplice (na podstawie Szuflicki i in., 2018)

Table 1. Register of clay raw material deposits in Lubsko, Jasień and Tuplice municipality (based on Szuflicki et al., 2018)

\begin{tabular}{|c|c|c|c|c|}
\hline \multirow[b]{2}{*}{$\begin{array}{l}\text { Nazwa złoża / } \\
\text { Name of deposit }\end{array}$} & \multirow[b]{2}{*}{$\begin{array}{c}\text { Gmina / } \\
\text { Munici- } \\
\text { pality }\end{array}$} & \multirow[b]{2}{*}{$\begin{array}{l}\text { Stan zagospodarowania / } \\
\text { The state of development }\end{array}$} & \multicolumn{2}{|c|}{$\begin{array}{l}\text { Zasoby }\left[\mathrm{mln} \mathrm{m}^{3}\right] / \\
\text { Resources }\left[\mathrm{mln} \mathrm{m}^{3}\right]\end{array}$} \\
\hline & & & $\begin{array}{l}\text { geologiczne } \\
\text { bilansowe / } \\
\text { anticipated } \\
\text { economic }\end{array}$ & $\begin{array}{l}\text { przemy- } \\
\text { słowe / } \\
\text { economic }\end{array}$ \\
\hline Glinka Górna & Lubsko & $\mathrm{Z}$ & 275 & - \\
\hline $\begin{array}{l}\text { Lubsko - Dachówczarnia I } \\
\text { (Mierków*) }\end{array}$ & Lubsko & Z & 1597 & - \\
\hline $\begin{array}{l}\text { Lubsko - Dachówczarnia II } \\
\text { (Lubsko A*) }\end{array}$ & Lubsko & Z & 1071 & - \\
\hline $\begin{array}{l}\text { Lubsko - Kaflarnia } \\
(\text { Lubsko B*) }\end{array}$ & Lubsko & $\mathrm{R}$ & 430 & - \\
\hline Lubsko - Szamotownia & Lubsko & Z & 1894 & - \\
\hline Budych I & Lubsko & \begin{tabular}{|c|} 
skreślone w 2017 / \\
removed from the list in 2017
\end{tabular} & - & - \\
\hline Jasień I & Jasień & $\begin{array}{c}\text { skreślone w } 2000 / \\
\text { removed from the list in } 2017\end{array}$ & - & - \\
\hline Jasień II & Jasień & E & 2012 & 871 \\
\hline Drzeniów & $\begin{array}{l}\text { Jasień, } \\
\text { Tuplice }\end{array}$ & Z & 381 & - \\
\hline Tuplice & Tuplice & $\mathrm{Z}$ & 382 & - \\
\hline
\end{tabular}

* nazwy istniejące przez pewien okres działalności zakładów, pojawiające się w niektórych dokumentach prawnych (inf. ustna E. i A. Kuźniar); Z - złoże, z którego wydobycie zostało zaniechane, R - złoże o zasobach rozpoznanych szczegółowo, E - złoże eksploatowane.

* historical name of the mine (information from E. and A. Kuźniar); Z - abandoned deposit, $\mathrm{R}$ - deposit covered by the detailed exploration, $\mathrm{E}-$ exploited.

Złoże Lubsko-Kaflarnia zajmuje powierzchnię 10,35 ha. W nakładzie występują gleby i piaski. Złoże zbudowane jest z iłów serii poznańskiej o miąższości 5-14,4 m (Maćków i in., 2006).

Dawne złoże bilansowe Budych I udokumentowano na powierzchni 25,5 ha (Maćków i in., 2006). Zbudowane jest z iłów szarych, zielonawoszarych, miejscowo pstrych, z przejściami do szarozielonawych mułków i piasków. Występuje tutaj $50-70 \%$ minerałów ilastych. Głównym składnikiem jest beidellit, towarzyszą mu kaolinit, illit oraz w śladowych ilościach chloryt. Poza wymienionymi minerałami ilastymi występują też: kwarc, getyt, hematyt, syderyt (Kozydra \& Wyrwicki, 1978).

Złoże Jasień I budują głównie iły zielonawoszare, wykazujące miejscami przejścia do mułków, sporadycznie piasków mniej lub bardziej ilastych. W zło- 
żu tym występują konkrecje węglanu wapnia, co odróżnia je od złóż lubskich. Złoże zawiera 55-75\% minerałów ilastych. Występuje tutaj głównie beidellit, jednak miejscowo kaolinit występuje z nim w równowadze. Akcesorycznym składnikiem jest illit. Określono również, że istotnym składnikiem jest kwarc oraz piryt, a także muskowit i getyt (Kozydra \& Wyrwicki, 1978).

Złoże Drzeniów o powierzchni 5,9 ha składa się z wzajemnie przeławicających się iłów szarozielonawych, pstrych oraz jasno i ciemnoszarych. Głównym składnikiem jest beidellit, illit lub kaolinit. Występuje także kwarc, getyt, muskowit oraz skalenie (Maćków i in., 2006; Kozydra \& Wyrwicki, 1978)

\section{Historia eksploatacji}

Przydatność lubskich iłów została odkryta już w średniowieczu. Surowiec ten był używany do wyrobów ceramiki użytkowej oraz budowlanej. Garncarstwo tworzyło mocne lobby gospodarcze Lubska, zaraz po płóciennictwie i sukiennictwie. Do kresu mało wydajnej produkcji (indywidualne warsztaty, małe kaflarnie, prymitywne piece do wypalania cegły) przyczyniło się otwarcie kolei żelaznej w roku 1846. Po wojnie prusko-francuskiej (1870-1871) Niemcy otrzymały od Francji kontrybucję wojenną. Za uzyskane pieniądze wznoszono liczne budynki użyteczności publicznej, wobec czego zapotrzebowanie na surowce budowlane było wysokie. $\mathrm{W}$ tym czasie w Lubsku powstawały kolejne wyrobiska iłów i wznoszono liczne zakłady przeróbcze. Duża część produktów trafiała do Berlina (Majchrzak, 1998).

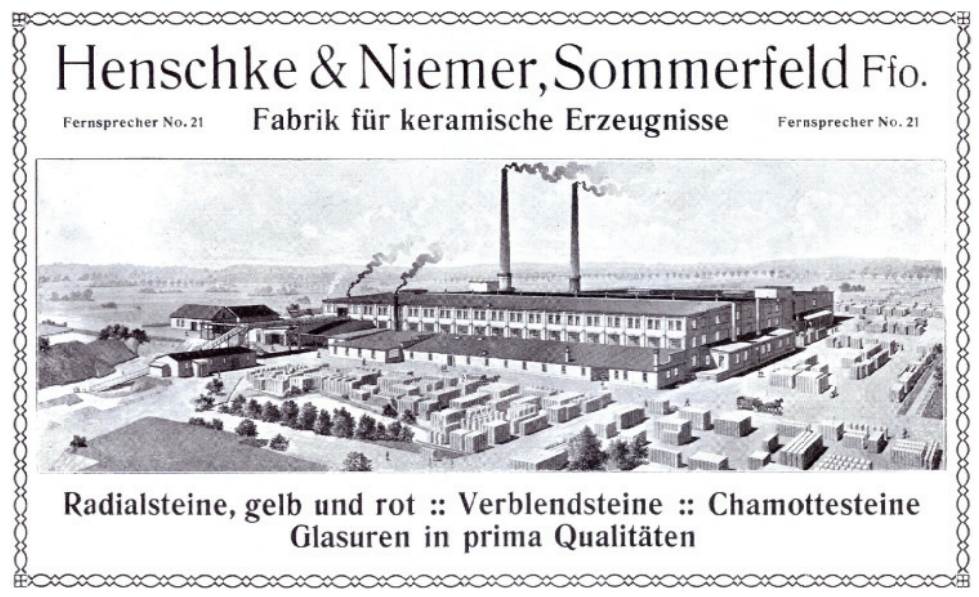

Ryc. 2. Reklama fabryki Henschke und Niemer (Köppen, 1908)

Fig. 2. Advert of Henschke und Niemer enterprise (Köppen, 1908) 
W roku 1908 w Lubsku (wtedy Sommerfeld) działały firmy związane z produkcją wyrobów ceramicznych: Freytag, Roll i Kreutz, Niemer i Henschke (ryc. 2), Teschendorff, Märkische Tonwerke, Ton- und Dachsteinwerke Oberklinge oraz mała fabryka Lachmann. W Jasieniu (wtedy Gassen) natomiast funkcjonowały fabryki Balack i Wirsich oraz Th. Freytag i Co. Produkowane były cegły, dachówki oraz rury. Ze względu na znaczące zapotrzebowanie na pracowników zatrudniano ludzi $\mathrm{z}$ pobliskich wsi, ale również obcokrajowców (Köppen, 1908).

Po I wojnie światowej rozwój miasta spowolnił, stan ten trwał do roku 1945 (Dzwonkowski, 2018). Należy również wspomnieć, że w latach 1940-1944 w mieście istniało kilkanaście obozów pracy przymusowej dla cudzoziemców. Część z obozów została utworzona w zakładach ceramicznych (Majchrzak, 1998).

W roku 1945 miasto zostało wyzwolone przez Armię Czerwoną. W początkowym okresie powojennym miało miejsce intensywne nasiedlanie ludności repatriowanej z byłych terenów Polski Wschodniej, Centralnej, a także ludności przybywającej z Europy Zachodniej. Po zakończeniu tego procesu podjęto się odbudowy lubskiego przemysłu. W tym czasie zakłady ceramiczne podlegały Poznańskim Zakładom Ceramiki Budowlanej. Napotykano liczne problemy takie jak: brak pracowników, przestarzały park maszynowy, utrudniony dostęp do materiałów zaopatrzeniowych i części zamiennych (Kuźma, 1971). W latach powojennych w zakładach wspólnie pracowali Polacy oraz jeszcze nieprzesiedlona ludność niemiecka. Część produktów była kierowana na odbudowę Warszawy (inf. ustna P. Kaczan).

Przedwojenna historia lubskiego przemysłu jest w niewielkim stopniu opisana w języku polskim. W celu jej odtworzenia konieczna będzie analiza niemieckojęzycznych dokumentacji oraz akt miasta.

W roku 1951 utworzono Przedsiębiorstwo Państwowe pod nazwą Lubskie Zakłady Ceramiki Budowlanej. W jego skład weszły lubskie zakłady: Glinka Górna, Budych I, Budych II, Lubsko - Kaflarnia, Szamotownia, Lubsko - Dachówczarnia I i Lubsko - Dachówczarnia II, a także zakład w Drzeniowie (Drzeniów), oraz dwa zakłady w Jasieniu: Jasień oraz Jasień II (Zarządzenie..., 1951; ryc. 3).

W latach późniejszych dochodziło do różnych zmian organizacyjnych. Do istotniejszych należy ta z roku 1953, kiedy to zakłady Jasień I, Jasień II oraz Drzeniów zostały odłączone i utworzono Żarskie Zakłady Ceramiki Budowlanej z siedzibą w Jasieniu. W roku 1954 Łódzkie Zakłady Ceramiki Budowlanej przejęły Kaflarnię. W roku 1959 Kaflarnia powróciła do LZCB, a w roku 1961 także Jasień I, Jasień II i Drzeniów. W roku 1966 do przedsiębiorstwa włączono także zakład w Tuplicach (Kuźma, 1971).

Lubskie Zakłady Ceramiki Budowlanej istniały do roku 1970, nastąpiło wtedy połączenie z zakładami w Gozdnicy (Gozdnickie Zakłady Ceramiki Budowlanej) 
i powstało Lubuskie Przedsiębiorstwo Ceramiki Budowlanej z siedzibą w Gozdnicy. Zakłady były niedoinwestowane, mało opłacalne, bardzo energochłonne (ze względu na stosowane przestarzałe piece Hoffmana i suszarnie Kellera), często działały na maszynach poniemieckich (inf. ustna E. i A. Kuźniar).

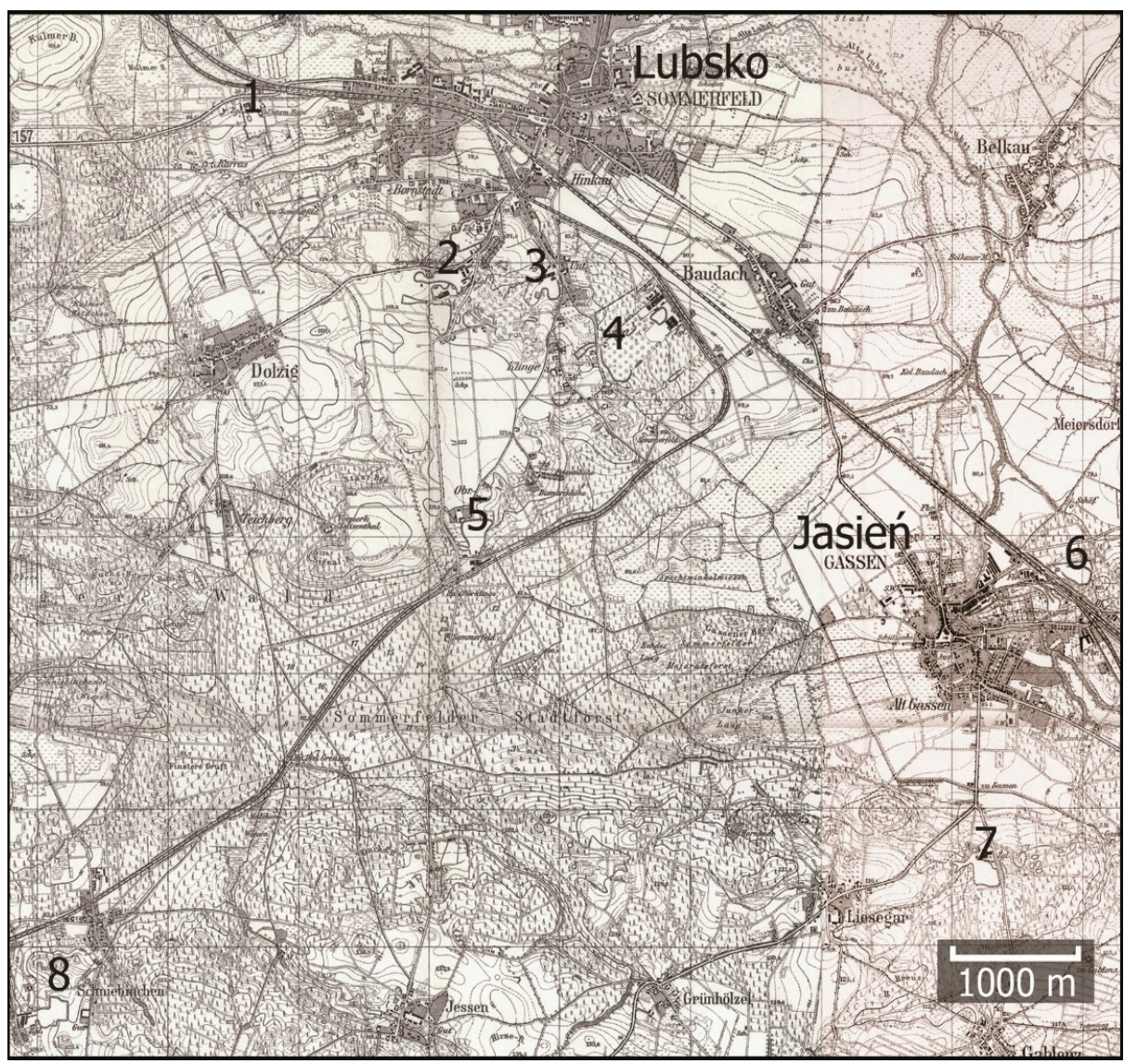

Ryc. 3. Rozmieszczenie zakładów ceramicznych w Lubsku i Jasieniu i ich okolicach; 1 - Dachówczarnia I, 2 - Szamotownia, 3 - Dachówczarnia II oraz Kaflarnia, 4 - Budych, 5 - Glinka Górna, 6 - Jasień I, 7 - Jasień II, 8 - Drzeniów (na podstawie Meßtischblatt, 1939a i 1939b)

Fig. 3. Location of ceramic factories in Lubsko, Jasień and theirs surroundings;

1 - Dachówczarnia I, 2 - Szamotownia, 3 - Dachówczarnia II and Kaflarnia, 4 - Budych, 5 - Glinka Górna, 6 - Jasień I, 7 - Jasień II, 8 - Drzeniów (adopted from Meßtischblatt, 1939a and 1939b)

W zakładzie Glinka Górna eksploatacja odbywała się przy wykorzystaniu koparki wielonaczyniowej pracującej podsiębiernie, transport odbywał się na hałdę tymczasową, z której następnie kolejna koparka przenosiła urobek na 
wózki kolebowe ciągnione przez lokomotywę spalinową. Kopalnia ta była wyjątkowa, $\mathrm{z}$ tutejszych iłów produkowana była cegła kominowa, którą wysyłano do Nowej Huty. Kres wytwarzania tego produktu przypadł na początek lat 70., ze względu na pojawienie się w złożu kopaliny o zbyt niskiej jakości. W latach późniejszych produkowana była głównie tzw. galeta (inf. ustna E. i A. Kuźniar). Były to bloki wstępnie przerobionej masy ceramicznej o wielkości kilku cegieł (Olszewski i in., 1989). Eksploatacja tego złoża była prowadzona przez prywatnych przedsiębiorców jeszcze po roku 2010 (Geoportal, 2018).

Zakład Dachówczarnia I (dawniej Mierków) produkował rury drenarskie i cegłę dziurawkę. Eksploatacja prowadzona była w wyrobisku stokowym. Zakład Dachówczarnia II natomiast produkował m.in. klinkier oraz rury drenarskie. Był przy nim zlokalizowany gmach dyrekcji głównej oraz drugi budynek techniczny, w którym znajdował się zakład przeróbczy (inf. ustna E. i A. Kuźniar). W latach osiemdziesiątych miał miejsce pożar budynku technicznego. W jego wyniku spłonął dach, został on jednak szybko wyremontowany a produkcja wznowiona (Ceramik, 2018; ryc. 4).

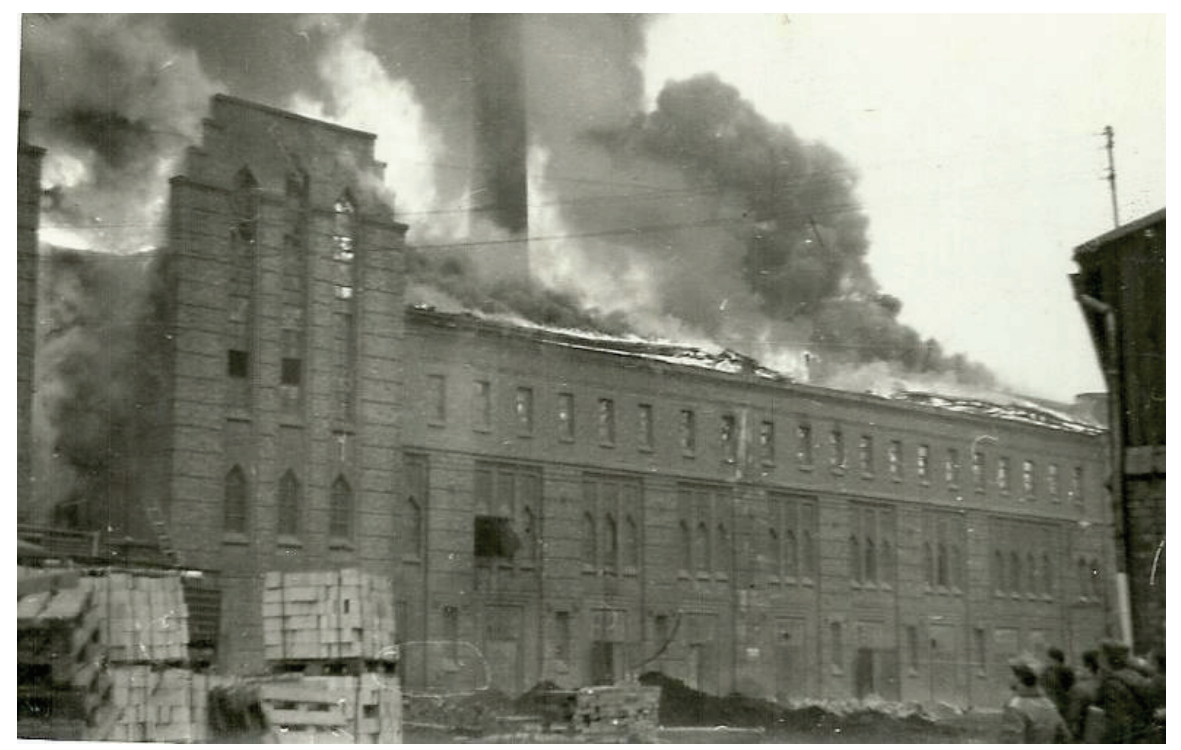

Ryc. 4. Pożar budynku technicznego Dachówczarnia II w latach osiemdziesiątych (www.facebook..., 2018)

Fig. 4. Dachówczarnia II technical building fire in the 1980s (www.facebook..., 2018)

Zakład Budych umiejscowiony był w niedalekiej odległości od Dachówczarni II i należało do niego wiele wyrobisk (ryc. 5). Te zlokalizowane na północnym-zachodzie obszaru górniczego powstały przed rokiem 1965. Eksploata- 
cja na wschodnim wyrobisku została dokończona w latach późniejszych. Największa odkrywka, leżąca w południowej części obszaru osiągnęła swoje obecne rozmiary w latach 1970-1980 (inf. ustna E. i A. Kuźniar).

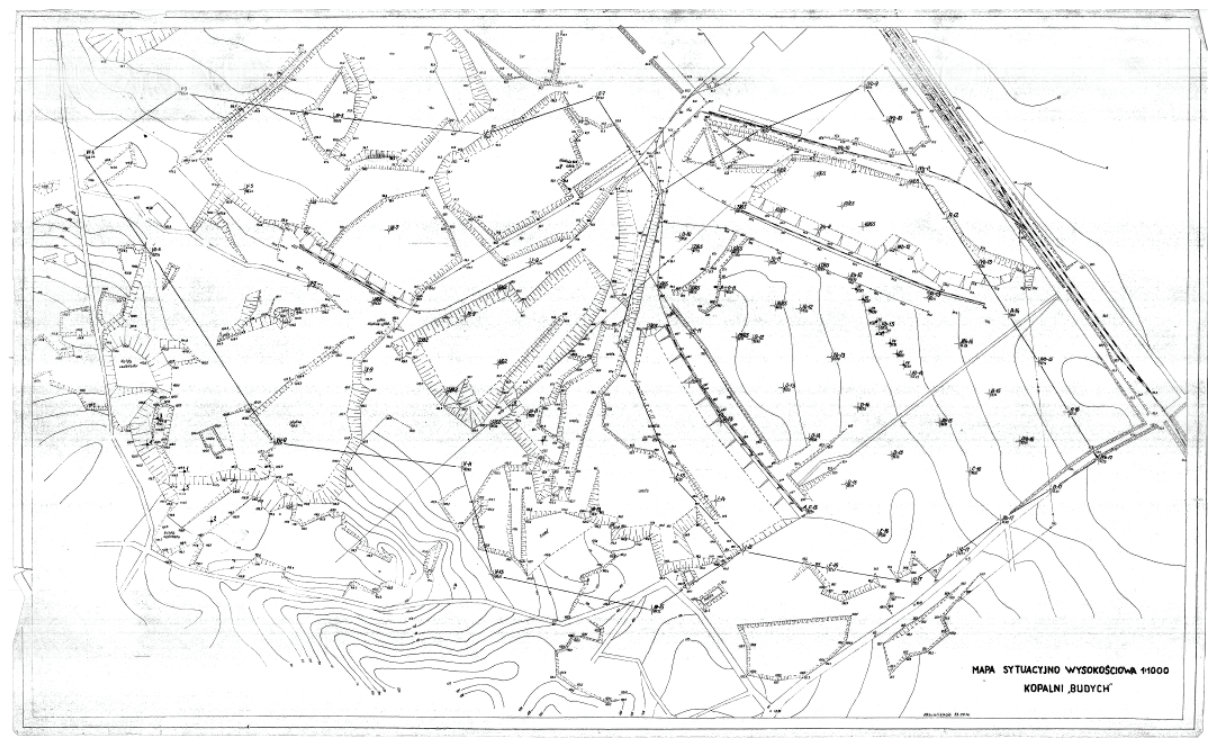

Ryc. 5. Plan sytuacyjno-wysokościowy zakładu Budych; liczne, rozproszone po całym obszarze wyrobiska odkrywkowe; trakcja kolejowa prowadząca od ścian eksploatacyjnych do zakładu przeróbczego (materiały otrzymane od E. i A. Kuźniar)

Fig. 5. Situation-altitude plan of Budych open-pits; numerous open-pits spread withing whole mining area; railway tracks leading from the bench wall to the plant (received from E. and A. Kuźniar)

Zakład Szamotownia w roku 1965 już nie funkcjonował, w latach późniejszych w wyrobisku powstawało składowisko odpadów, które następnie zostało zrekultywowane, a w latach 2013-2014 na powierzchni powstała stacja przeładunkowa odpadów (inf. ustna E. i A. Kuźniar).

Kres przemysłowej, scentralizowanej produkcji związany był z przemianami ustrojowymi zachodzącymi w Polsce. W wyniku prywatyzacji Budych, Glinka górna, Dachówczarnia I, Dachówczarnia II, Drzeniów, Tuplice oraz zakłady jasieńskie weszły $\mathrm{w}$ ręce prywatnych inwestorów, którzy wcześniej składali listy intencyjne. Zakłady utrzymywały się przez krótki okres, większość z nich bardzo szybko zakończyła produkcję, a infrastruktura szybko zaczęła ulegać niszczeniu i rozbiórce (inf. ustna E. i A. Kuźniar).

Obecnie na terenie gminy Lubsko żadne złoże nie jest zagospodarowane. W roku 2014 grupa przemysłowa IndygoTech Minerals S.A. zainwestowała w spółki Baltic Ceramics Investments oraz LZMO. Pierwsza z nich zarządzała 
projektem budowy fabryki proppantów ceramicznych, użytkowanych w procesie poszukiwania i wydobycia gazu oraz ropy. Produkt ten to materiał stanowiący do 9,5\% płynu szczelinującego. Składa się z niepalnych ziaren stałych - w tym przypadku iłów. Materiał ten, dostarczany do wyrobisk górniczych przy użyciu ciekłego medium osadza się i tworzy podporę mechaniczną. Umożliwia to swobodny przepływ gazu przez szczeliny (Mizera i in., 2016). Budowa zakładu wytwarzającego ten produkt była prowadzona w ramach projektu „Wdrożenie wynalazku w zakresie wytwarzania lekkich proppantów ceramicznych" realizowanego w ramach pilotażu „Wsparcie na pierwsze wdrożenie wynalazku Programu Operacyjnego Innowacyjna Gospodarka, na lata 2007-2013”, współfinansowanego ze środków Europejskiego Funduszu Rozwoju Regionalnego.

Druga spółka zajmowała się produkcją oraz handlem ceramicznymi wkładami i systemami kominowymi. Formowanie wkładów odbywać się miało przy wykorzystaniu innowacyjnej technologii izostatycznej (www.indygotechminerals..., 2018). W roku 2018 sąd ogłosił upadłość LZMO (www.stockwatch..., 2018). Spółka Baltic Ceramics Investments w raportach kwartalnych od roku 2016 do II kwartału 2018 wskazuje, że ze względu na brak środków, budowa nowoczesnego zakładu nie została ukończona, więc nie jest prowadzona działalność produkcyjna. Raporty wskazują, że skupiono się na pracach badawczo-rozwojowych, które prowadzi spółka zależna Pro Ceramics (wcześniej Baltic Ceramics; www.balticceramics..., 2018). Działania te jednak na chwilę obecną nie dają jasnych, namacalnych wyników, a spółka Pro Ceramics jest w stanie upadłości (www.imsig..., 2018).

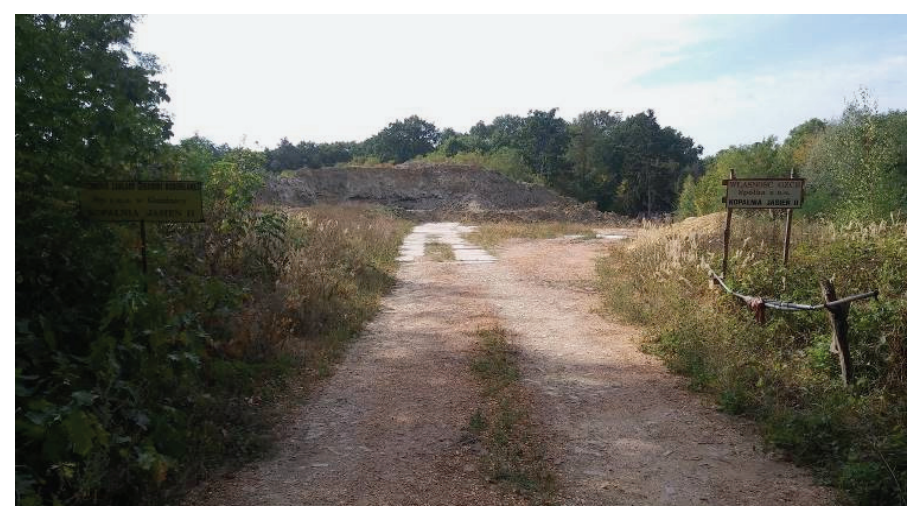

Ryc. 6. Wjazd do kopalni Jasień II we wrześniu 2018 roku

Fig. 6. Entrance to the Jasien II mine in september 2018

Jak wspomniano wcześniej, wciąż działającym w tym rejonie zakładem jest Kopalnia Jasień II. Podczas zwiadu terenowego nie zauważono pracujących maszyn, jednak stan obiektu jak i samej odkrywki wskazuje, że prowadzona jest 
w tym miejscu eksploatacja okresowa (ryc. 6). Złoże objęte jest koncesją na wydobywanie (Geoportal..., 2018). Wjazdy do kopalni zabezpieczone są szlabanami i oznaczone tablicami informacyjnymi.

\section{Pozostałości górnicze}

Wynikiem działalności górniczej na obszarze gminy Lubsko, Jasień i ich okolic, są liczne wyrobiska odkrywkowe, oraz pozostała infrastruktura pogórnicza. Bardzo istotny jest wspomniany wcześniej fakt, że po zamknięciu zakładów dochodziło do intensywnego rozkradania mienia i idącego za tym niszczenia budynków. Przykładem wyniku tych działań jest stan zachowania infrastruktury położonej przy złożu Dachówczarnia II (ryc. 7a, c). Budynek

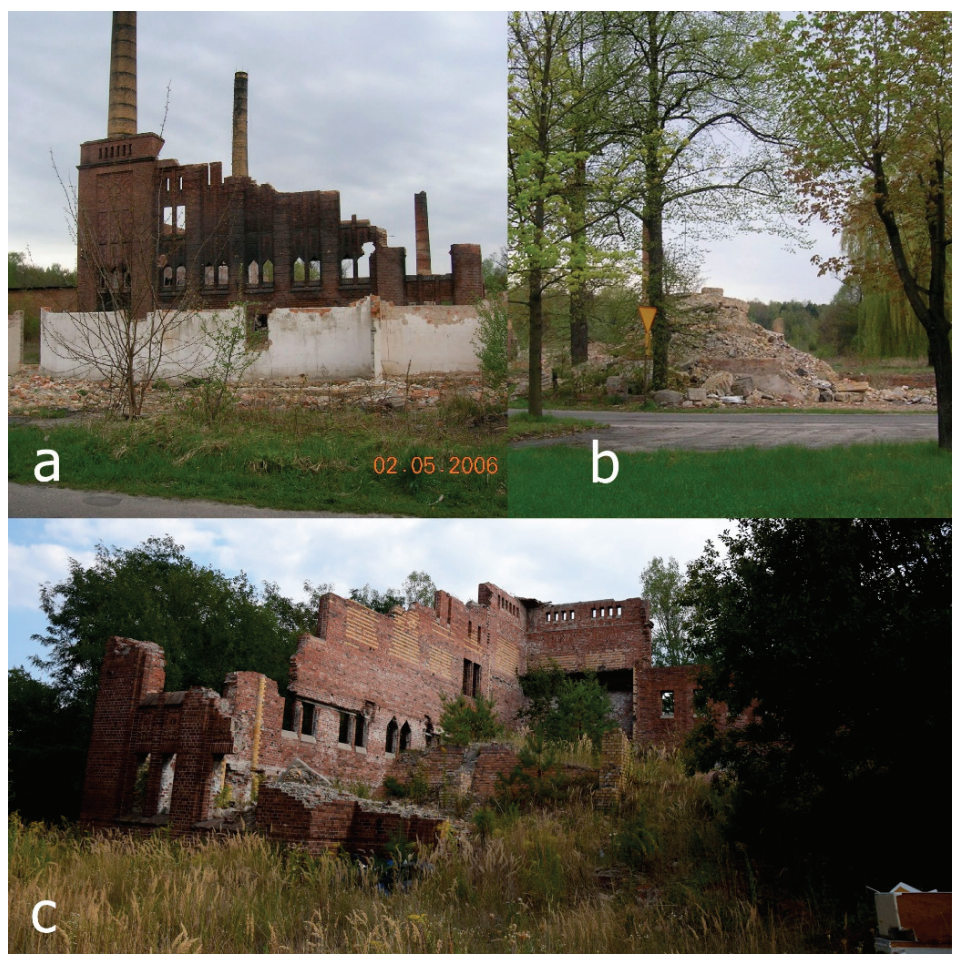

Ryc. 7. Infrastruktura zakładu Dachówczarnia II: a - stan budynku technicznego w roku 2006, widok od ul. Głowackiego; b - resztkowe ruiny budynku administracji w roku 2006; c - stan budynku technicznego od przeciwnej strony w roku 2018 (arch. własne autora)

Fig. 7. Dachówczarnia II infrastructure: a - the condition of the technical building in 2006; $\mathrm{b}$ - remainings of the administration building in 2006;

$\mathrm{c}-$ the condition of the technical building from the back side in 2018 (author's archive) 
techniczny został w większości rozebrany, a jego teren ulega ciągłemu zanieczyszczaniu odpadami oraz zarastaniu przez roślinność. Położony kilkadziesiąt metrów od niego budynek administracyjny był sukcesywnie rozkradany i rozbierany, aż do niemal całkowitego zniszczenia (ryc. 7b). Wyrobiska przy tym zakładzie są wypełnione wodą, a teren jest strzeżony ogrodzeniem betonowym.

Jako przykład prawidłowego zagospodarowania należy wyróżnić odkrywkę Jasień I. Obiekt ten został wzięty pod opiekę przez Polski Związek Wędkarski - Okręg w Zielonej Górze. Wjazd na staw jest zabezpieczony szlabanem (ryc. 8). Wybudowano altanę dla przebywających na tym terenie. Tereny wokół wyrobiska są zadbane - postawiono ławki, oraz kosze na odpady

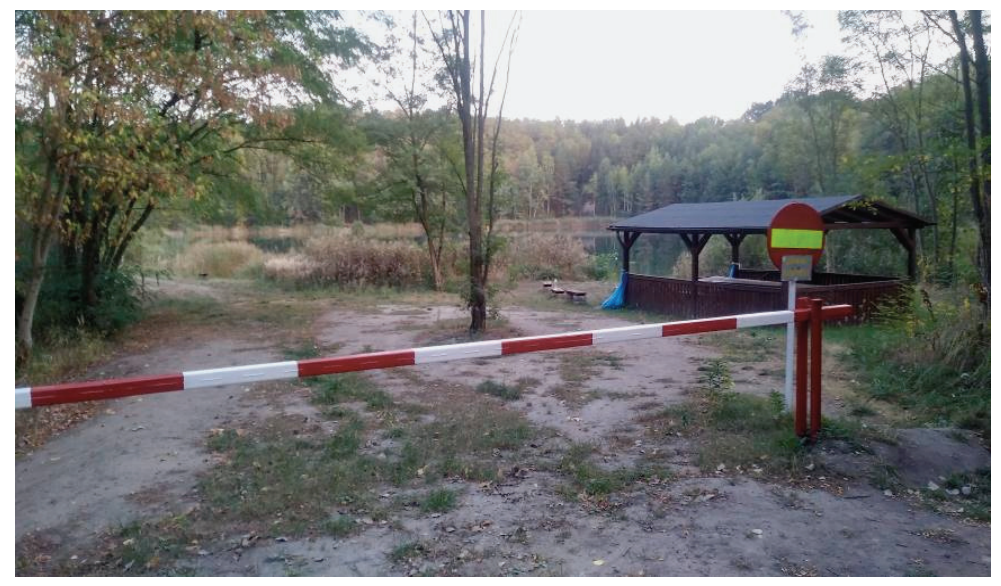

Ryc. 8. Wjazd na teren dawnego zakładu Jasień I; stan na wrzesień 2018

Fig. 8. The entrance to the former Jasień I plant in September 2018

Kolejnym opisywanym zakładem jest Szamotownia, jak wspomniano wcześniej, w wyrobisku dokonywano składowania odpadów komunalnych aż do roku 2013, wtedy to w wyniku przetargu wybrano ofertę firmy EUROBUD, która następnie przeprowadziła proces rekultywacji (Marszów..., 2018; ryc. 9). W roku 2014 doszło również do otwarcia stacji przeładunkowej odpadów. Infrastruktura została wybudowana przez firmę AK NOVA (www.aknova..., 2018). Obie te inwestycje przeprowadzono w ramach projektu pod nazwą „Gospodarka odpadami w obrębie powiatów żarskiego i żagańskiego". Obecnie teren wokół sortowni pokrywają łąki.

Inne opisywane obiekty zostały w głównej mierze zrekultywowane w kierunku leśnym i wodnym oraz uległy sukcesji naturalnej. Tereny odkrywek porastają lasy, krzewy, trawy, a ich najgłębsze części uległy zabagnieniu. W miejscach tych często można natrafić na wędkarzy, a także osoby spacerujące. 
Częstą praktyką jest także organizowanie rajdów dla quadów i samochodów terenowych na terenach wokół wyrobisk. Obecnie w miejscach tych można znaleźć tylko nieznaczne znamiona dawnej działalności przemysłowej. Przykładem są elementy trakcji na jednym z wyrobisk zakładu Budych.

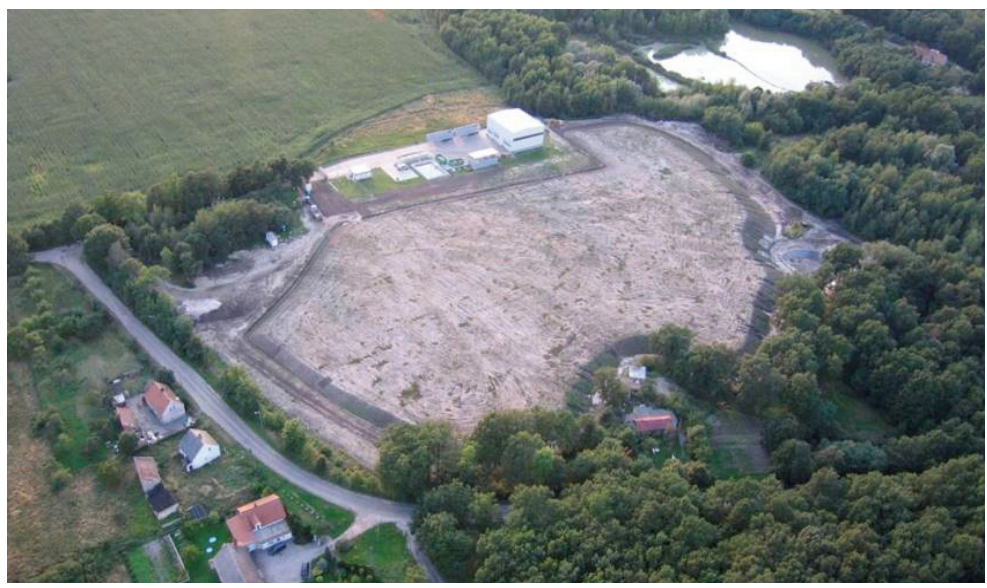

Ryc. 9. Składowisko odpadów komunalnych w Lubsku w trakcie rekultywacji w roku 2014; na zdjęciu widoczna jest infrastruktura stacji przeładunkowej odpadów

(fot. A. Cierpiński; marszów..., 2018)

Fig. 9. The landfill in Lubsko during the reclamation in 2014; photo shows infrastructure of the waste sorting plant (photo A. Cierpiński; marszów..., 2018)

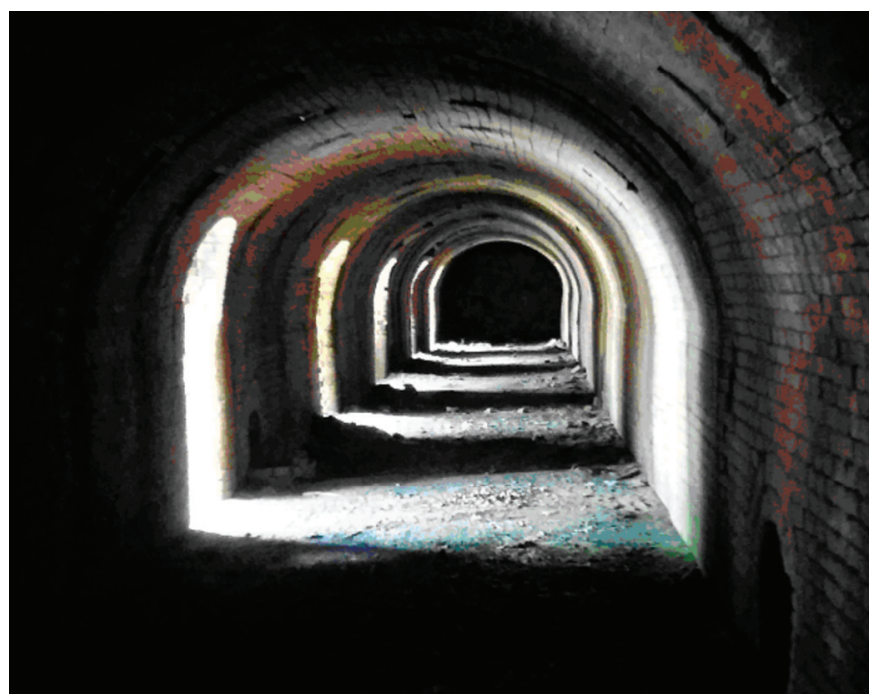

Ryc. 10. Wnętrze pieca Hoffmana w zakładzie Glinka Górna

Fig. 10. The interior of Hoffman Kiln - Glinka Górna 
W krajobraz Lubska wpisują się niszczejące kominy i budynki dawnych zakładów. Na szczególną uwagę zasługują budynki zakładów Dachówczarnia I oraz Glinka Górna. Pozostała infrastruktura w tych miejscach to istotne znamiona dawnej działalności zakładów ceramicznych. Zachowały się w nich m.in. piece Hoffmana (ryc. 10) oraz suszarnie Kellera.

\section{Podsumowanie}

Występowanie licznych złóż surowców ilastych na terenie gmin Lubsko i Jasień oraz ich okolic pozwoliło na rozwój przemysłu ceramicznego. Dawne niewielkie prywatne garncarnie przerodziły się $\mathrm{w}$ zorganizowane zakłady przemysłowe, które intensywnie eksploatowały złoża iłów i wytwarzały z nich wyroby ceramiczne. Przemiany ustrojowe Polski rozpoczęły likwidowanie tego ważnego dla miasta i regionu przemysłu. Obecnie liczne zakłady rozproszone na opisywanym terenie są tylko częścią krajobrazu. Użytkowanie wyrobisk, jak i pozostałej infrastruktury jest różnorodne. Mimo to wiele z tych obiektów pozostaje niezagospodarowanych. Postępujące niszczenie budynków jest procesem intensywnym i nieodwracalnym. Efektem tego może być utracenie nieodłącznych elementów historii Lubska i Jasienia. Ze względu na ten fakt istotne jest dokumentowanie obecnego stanu pozostałości górniczych tego regionu.

\section{Literatura}

DZWONKOWSKI T., Wstęp do akt miasta Lubsko. Arch. Nar. w Zielonej Górze, 89/1519/0, dostępny na stronie: https://szukajwarchiwach.pl/89/1519/0/?q=lubsko+XTYPEro:zesp +XARCHro: 89iwynik=60irpp=15ipage=4\#tabZespol (dostęp: kwiecień 2019).

BARTCZAK E., 2001. Objaśnienia do szczegółowej mapy geologicznej Polski 1:500, Ark. Zasieki i Lubsko. Wyd. PIG, Min. Środ. Warszawa.

geolog.pgi.gov.pl - mapa interaktywna na witrynie internetowej PIG (dostęp: grudzień 2018). geoportal.pgi.gov.pl/portal/page/portal/midas - MIDAS, System Gospodarki i Ochrony Bogactw Mineralnych (dostęp: grudzień 2018).

KOZYDRA Z., WYRWICKI R., 1978. Surowce ilaste poludniowej części Ziemi Lubuskiej. Kwart. Geol., 22, 2: 227-253.

KÖPPEN A., 2011. Sommerfeld in der Niederlausitz mit Gassen und Umgegend nebst Industrie, Handel und Gewerbe in Wort und Bild. Niederlaustiz Verlag, Guben (reprint wydania z 1908 r.). KUŹMA H., 1971, Rozwój Zakładów Ceramiki Budowlanej w Lubsku w okresie 25-lecia PRL. Bibl. Publ. w Lubsku. Praca niepublikowana.

MAJCHRZAK J.P., 1998. Miasto ze złotym lwem w herbie. Dom Wydawn. Soravia. Żary. marszow.pl - witryna internetowa Zakładu Zagospodarowania Odpadami (dostęp: grudzień 2018).

MIZERA J., WIŚNIEWSKI P., SZYMAŃSKA J., 2016. Polskie proppanty ceramiczne podpora rewolucji lupkowej. [w:] Paliwa i Energetyka, styczeń-marzec 1/2016/16. 
MYK T., 1977. Środowisko geograficzne Lubska, Jasienia i okolic. [W:] W. Hładkiewicz, J. Koniusz J. Zeszyty Lubuskie. Lubsko-Jasień, z dziejów i współczesności. Lubuskie Tow. Kultury. Zielona Góra.

MAĆKÓW A., BOJAKOWSKA I., DOBEK P., PASIECZNA A., TOMASSI-MORAWIEC H., 2006. Objaśnienia do mapy geośrodowiskowej Polski 1:50 000, Ark. Lubsko. Wyd. PIG, Min. Środ. Warszawa.

Meßtischblatt 4255, Sommerfeld 1939a. Königl. Preuss. Landes-Aufnahme. Berlin. Dostęp na http://igrek.amzp.pl (dostęp: kwiecień 2019).

Meßtischblatt 4256, Gassen 1939b. Königl. Preuss. Landes-Aufnahme. Berlin. Dostęp na http://igrek.amzp.pl (dostęp: kwiecień 2019).

OLSZEWSKI J., OSUCHOWSKI J., PILECKI J., PLUTA L., PRZYBYŁA M., SZCZEPAŃSKI Z., ZAJDEL F., 1989, Leksykon Górniczy, Wydawnictwo „Śląsk”, Katowice.

SZUFLICKI M., MALON A., TYMIŃSKI M. (red.), 2018. Bilans zasobów złóż kopalin w Polsce wg stanu na 31 XII 2017 r. PIG-PIB. Warszawa.

www.aknova.com.pl - witryna internetowa firmy inżynieryjnej AK NOVA (dostęp: grudzień 2018).

www.balticceramics.com - witryna internetowa spółki Baltic ceramics investments (dostęp: grudzień 2018).

www.facebook.com/Ceramik-Lubsko-503860086384359 - fanpage Ceramik Lubsko, Facebook (dostęp: grudzień 2018).

www.imsig.pl - Internetowy monitor sądowy i gospodarczy (dostęp: grudzień 2018).

www.indygotechminerals.com - witryna internetowa spółki Indygo Tech Minerals S.A. (dostęp: grudzień 2018).

http://otworywiertnicze.pgi.gov.pl - Internetowa baza danych Polskiego Instytutu Geologicznego dotycząca otworów wiertniczych (dostęp: kwiecień 2019).

www.stockwatch.pl - Serwis internetowy StockWatch dostarczający bieżące dane finansowe spółek (dostęp: grudzień 2018).

ZARZĄDZENIE Ministra Przemystu Lekkiego w sprawie utworzenia Przedsiębiorstwa Państwowego pod nazwa Lubskie Zakłady Ceramiki Budowlanej, 1951. Arch. Nar. w Zielonej Górze, $89 / 2581 / 0 / 1.1 / 1$.

\title{
MINING AND PROCESSING OF CLAY RAW MATERIALS IN LUBSKO, JASIEŃ AND ITS SURROUNDINGS (WESTERN POLAND)
}

\author{
Lubsko, Jasień, Sommerfeld, Gassen, \\ clay raw materials, ceramics
}

Lubsko is a small town in western part of Poland. Deposits of clay raw materials in this area were well known in middle ages. Back in those days production existed as a cottage industry. Development of mining occurred in XIX and XX century due to the construction of a new railway line across this region. The end of this industry branch is related to the political changes in Poland in the late 80 's. Nowadays, only one mine is operating in this area. The mining left significant impact on Lubsko's history and morphology. This article describes geology of the region, its deposits and history of the mining and processing of clay raw materials. Moreover, the recent condition of the mining remainings is described and documented with photos. 